\title{
The waste prevention kit for enterprises, education, and households (WastePrevKit)
}

\author{
R.-L. M. Hahtala ${ }^{1}$, S. R. Huuhtanen ${ }^{2}$, S. A. Kajaste ${ }^{1}$, A. E. Karhu ${ }^{1}$, \\ S. H. Kemppainen ${ }^{1}$, O. A. Linsiö ${ }^{1}$ \& M.-M. A. Partti ${ }^{1}$ \\ ${ }^{1}$ Helsinki Metropolitan Area Council (YTV), Waste Management, Finland \\ ${ }^{2}$ Helsinki Metropolitan Area Council (YTV), \\ Regional and Environmental Information, Finland
}

\begin{abstract}
The Helsinki Metropolitan Area Council (YTV) is responsible for organising the waste management in residential building areas around the metropolitan area. In 2002 the board of YTV accepted the Waste prevention at source strategy until 2007. Therefore, a 5-year project was launched to realise this strategy and this project is funded by the EU-LIFE -programme as a WastePrevKit project from 2005 to 2007. One of the main focus points of YTV is that by 2007 there will be less waste generated per inhabitant and workplace in the metropolitan area than in 2002. The waste prevention strategy consists of several subprojects. The most resources were devoted to the waste prevention at source and to linking effectively the way of thinking materially with the general education and vocational teaching. The models for smart ways of action drawn up in cooperation with educational institutions, enterprises and the public administration help for their part in reducing waste. The models are available for use in schools, shops, the building trade, offices and daycare centres. The waste benchmarking comparison service Petra is offered in YTV's webpages and provides a good tool for monitoring the waste amounts generated in workplaces, in educational institutions, companies and public administration properties. There are various kinds of awareness raising campaigns which are targeted at households. The webpages of waste prevention at source www.ytv.fi/fiksu are the focal point of the strategy.

Keywords: waste prevention, material efficiency, education, teaching material, benchmarking.
\end{abstract}




\section{Introduction}

The amount of waste is growing strongly in Europe despite the strict politicowaste targets. According to OECD's estimation the amount of MSW (municipal solid waste) will grow by $43 \%$ from 1995 onwards to 2020 [2]. The waste itself is, however, not the main problem, but the fact that over $90 \%$ of the natural resources utilised by people are immediately converted to waste during their products' and foods' manufacturing processes (Autio et al [3]). One of the goals of the EU's 6th Environmental Action Programme is to ensure that the use of renewable and non-renewable resources and their related impacts do not exceed the environment's carrying capacity.

Waste prevention is on the highest level of the target hierarchy of EU waste legislation. Waste prevention should be a primary measure. It must come before the reuse of waste as material or energy or final disposal. The EU is aiming for a significant cut in the amount of waste generated with help of new waste preventive initiatives and better usage of resources, as well as by encouraging a change towards more sustainable consumption patterns. According to the waste policy of the EU we should primarily reduce the amount of waste generated in the first place and reduce its hazardousness by reducing the presence of dangerous substances in products. However, waste prevention at source hasn't become an established term among ordinary citizens. Quite often sorting and recycling of wastes is understood as being part of waste prevention at source.

YTV's strategy concerning waste prevention at source includes the following subprojects:

- Material Efficiency in General Education (Smart Primary-school kid, Smart Pupil and Smart Student, web-based teaching materials from pre-primary level up to upper secondary stage)

- Material Efficiency in Vocational Education (Smart Professional, web-based teaching materials for vocational education institutions)

- Smart Ways of Action (SMAC) guides and checklists for waste prevention at source for educational institutions, companies and public administration

- Petra Waste Benchmarking Service for educational institutions, enterprises and public administration

- It's Smart with Less Waste -website (www.ytv.fi/eng/Fiksu/)

- Special awareness raising campaigns for households

\section{Strategy of waste prevention at source}

\subsection{Material efficiency in general education}

The Smart teaching materials, from preschool level up to upper secondary school, deal with the thematic of waste prevention at source with various methods suitable for each respective age and development stage of children and teenagers. The target is that by the end of 2007 each pupil will receive information on waste reduction and eco-efficiency three times during his/her entire school career: once during the pre-primary education, once in comprehensive school and once in upper secondary school. 
The teaching material is free of charge and available in electronic form in the net www.ytv.fi/fiksu. Pupils, students and teachers plus the other school personnel all participate in the waste reduction. Information on best practices of material efficiency is compiled in two models for schools and day-care centres. The models are also available on the Internet. Using these channels, low-waste ways of operating are easy to distribute more broadly.

A wide network has been established in the metropolitan area between the YTV waste management, municipal authorities, schools and daycare centres in order to provide the target groups with information on new materials and methods about waste prevention.

The project will monitor the waste flow information from school and nursery properties and register the obtained data in the waste benchmarking service Petra. Also the effectiveness of the project will be measured through questionnaires to the teachers.

\subsection{Material efficiency in vocational education}

The so-called virtual school projects of the vocational basic education have applied the information and communication technology for supporting the learning process, both in distance and contact teaching as well as in supervising the job-embedded learning. The diversification of the teaching arrangements and methods has been the aim and also the increasing of students' opportunities to study by utilising web-based instruction. Web-based teaching is already now an essential part of teaching in many schools (Leinonen et al [4]).

The stimulating and challenging material of material efficiency for the teachers in vocational education institutions was designed with help of the results from the Ammatti-KEKE project of the Finnish National Board of Education in 2002-2005 (Ammatti-KEKE $=$ the sustainable development in vocational training). In this the learning objectives and contents of sustainable development based on the curricula were written in to more than 20 institution-specific basic vocational qualifications at the practical level (Lundgren and Näätsaari [5]).

During the project about 60 teachers from vocational education institutions participated in the planning work of the teaching material together with consultants and other experts of the field. The electronic "Smart professional" teaching materials for technical, food, nutrition and institutional catering, as well as social and health care studies are available in YTV's Fiksu webpages www.ytv.fi/fiksu free of charge.

The material packages, including exercises, for vocational studies are connected to the curriculum of the basic degree of respective fields. The aim is that the viewpoint of waste prevention at source and material efficiency is an axiomatic part of vocational studies from beginning to end.

The goal is that teachers and students are able to apply the material efficient way of thinking in their own respective fields and that they recognise the environmental impact of their own actions. The material includes e.g. instructions for an environmental charting to be performed in the school. The model "Smart Ways in Educational Institutions" along with the checklists also helps to reduce waste in practice. 
The effectiveness of the project is being estimated by questionnaire studies for teachers and students for instance. The aim is that the teaching material will be used by $80 \%$ of the area's 25 vocational educational institutions in 2008 . The resent study shows that teachers in the field of food and nutrition have most actively applied this teaching material - although the number of the respondents was quite low in 2006 (Figure 1).

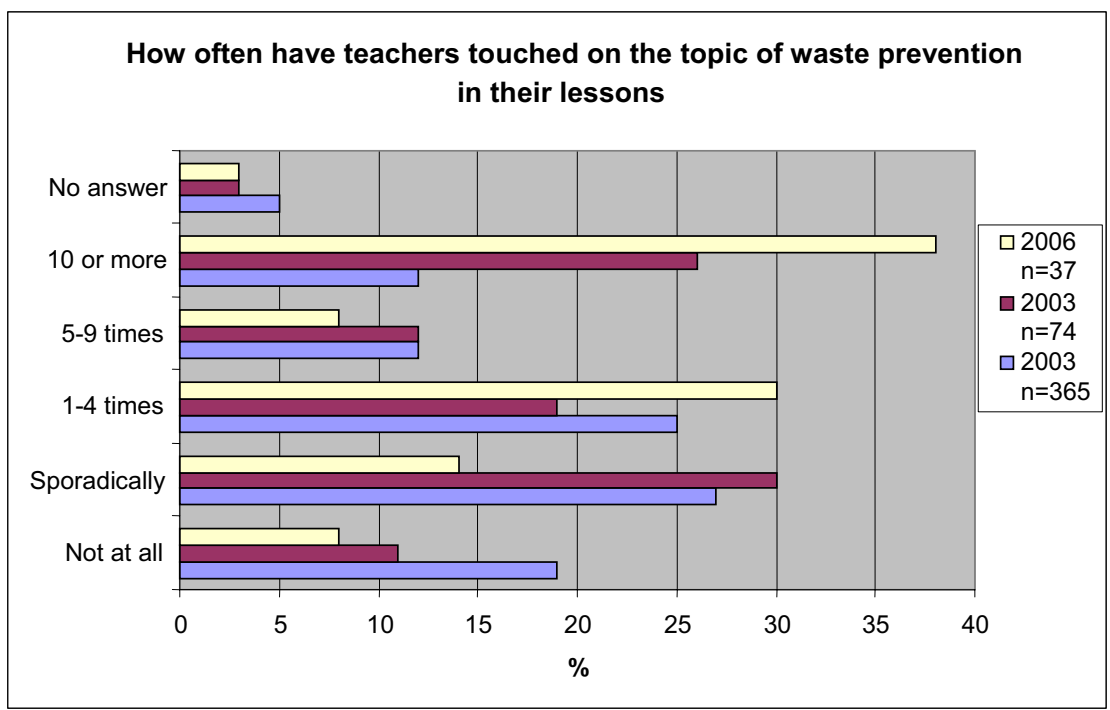

Figure 1: How often have teachers touched on the topic of waste prevention in their lessons during 2003 and 2006. In 2003 the questionnaire was sent to all teachers of vocational education institutions in the metropolitan area (the answering $\%=40$ ) incl. teachers in the field of food and nutrition (the answering \%=56). In 2006, the questionnaire was sent to the teachers in the field of food and nutrition (the answering $\%=30$ ).

\subsection{The models of Smart Ways of Action for schools, enterprises and the public administration}

Five models of the Smart Ways of Action have been drawn up together with different educational institutions, industrial enterprises and representatives of the public administration.

The models "Smart Ways of Action" for educational institutions [6] along with the checklists, help the personnel in reducing waste in practice. Smart Ways of Action in retail stores [7] is a tool directed particularly to the grocery and department stores for minimising the waste flows. Smart Ways of Action in the building trade [8] offers an extensive information package for construction professionals. The model of Smart Ways of Action for offices [9] is a tool to 
plan material efficient working methods applicable in office work. The model designed for daycare helps the personnel of daycare centres in waste issues in the premises of the daycare centres [10].

The aim is that models generating less waste are widely known and applied. The minimum objective for reducing waste amounts generated by stores and offices was defined as $3 \%$ from 2003 to 2006.

The waste generation (total amount of solid waste per employee) in the offices providing their waste data in the Petra Waste Benchmarking reduced from 2003 to 2005 . Especially the amount of waste paper and mixed waste in the offices has dropped. Figures for 2006 are not yet available (Figure 2).

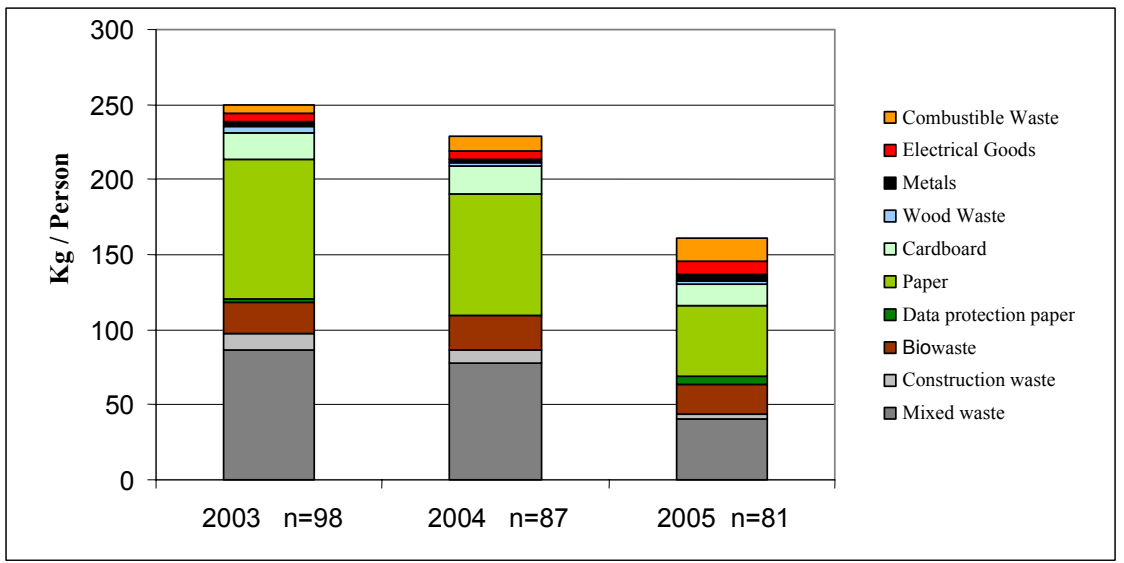

Figure 2: $\quad$ Total solid waste generation (kg/person) in offices 2003-2005 (Source: Petra Waste Benchmarking Database / YTV Regional and Environmental Information 1/2007).

The Smart Ways of Action (SMAC)-guides are available as pdf -files, published on the It's Smart With Less Waste web site [11]. Each SMAC -model consists of an electronic leaflet with information and tips on waste avoidance, active links to appropriate web sites and publications, and separate checklists.

\subsection{Petra - Waste Benchmarking service for schools, enterprises and the public administration}

The YTV's Waste Benchmarking service Petra is meant for following up waste amounts and is a cost-free, web-based tool available in YTV's webpages www.ytv.fi/petra [12]. The service is designed to help educational institutions, enterprises, organisations in developing their own waste management and reducing the waste amounts. With the help of this service a user is able to compare the waste amounts generated by it with other workplaces in the same field and with similar kinds of properties. With Petra it is easy to follow up how successful the preventive actions towards waste generation have been in each respective property. The aim is that the waste benchmarking system function 
well and smoothly and is being applied extensively in the Helsinki metropolitan area. It guides effectively educational institutions, companies and communities in reducing waste.

About 600 annual waste reports from educational institutions, companies and public organisations were checked and approved by the system administrator in 2006. The reports were gathered in cooperation with the Environment Centres (municipal environmental authorities) of the Helsinki Metropolitan Area municipalities (Helsinki, Espoo and Vantaa).

YTV encourages organisations to prevent waste at source by awarding yearly the Saver of Natural Resources award to those organisations which have reduced their waste amount in an exemplary manner. All organisations which have passed information to Petra waste benchmarking from Helsinki region participate automatically in this competition.

\subsection{Developing of a net portal}

The portal is an electronic data system which contains the teaching materials and other material of the project (www.ytv.fi/fiksu). A part of the portal content is also available in Swedish and English. The functionality and interactivity of the system is being improved constantly. The aim is that the net portal is practical and functional from the technical point of view. The contents of this portal are extensive and they inspire different target groups to start using it.

Charts of the portal monitoring system show that in average there has been approximately 20000 page views monthly during 2006 after modifications and changes in the portal (Figure 3). This year the amount of page views show a growing trend perhaps due to the marketing of the website. The results also show that Fiksu-portal is easily found by the search engines with waste prevention related keywords.

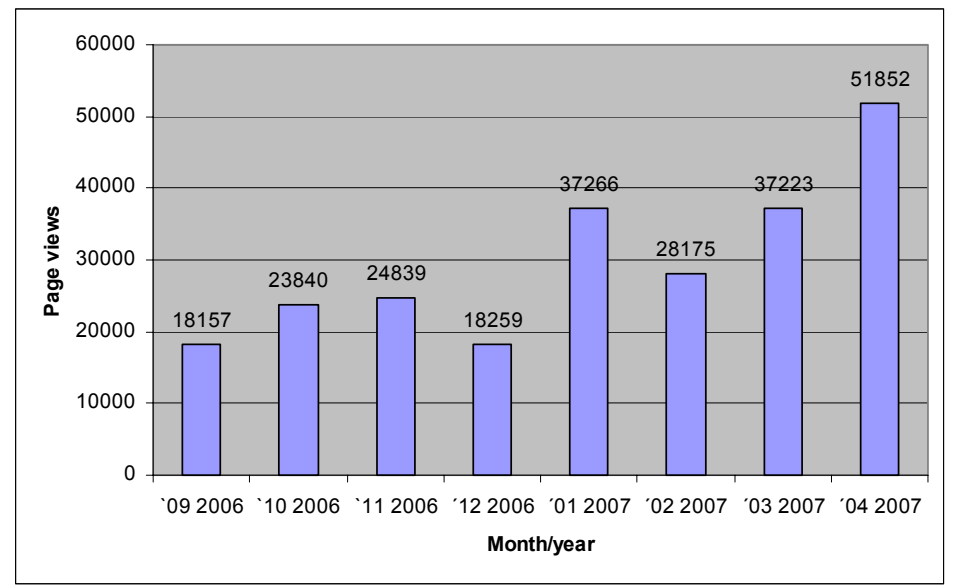

Figure 3: Monthly page views at the www.ytv.fi/fiksu web portal during September 2006-April 2007. 


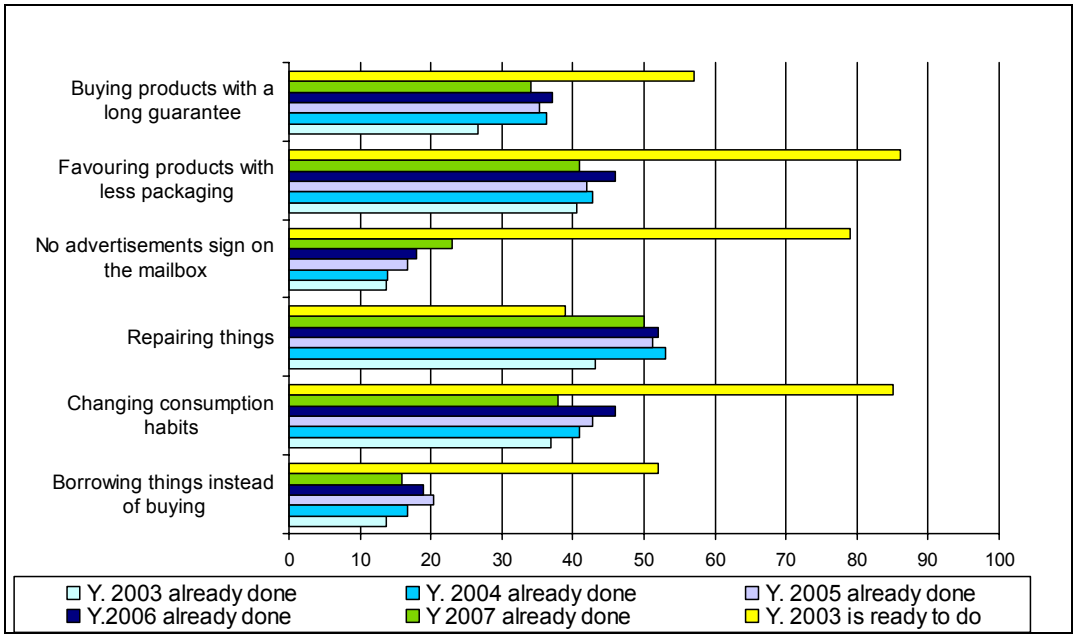

Figure 4: The willingness of the residents in Helsinki Metropolitan area to prevent waste versus intention (YTV's annual poll, n 1 000/year).

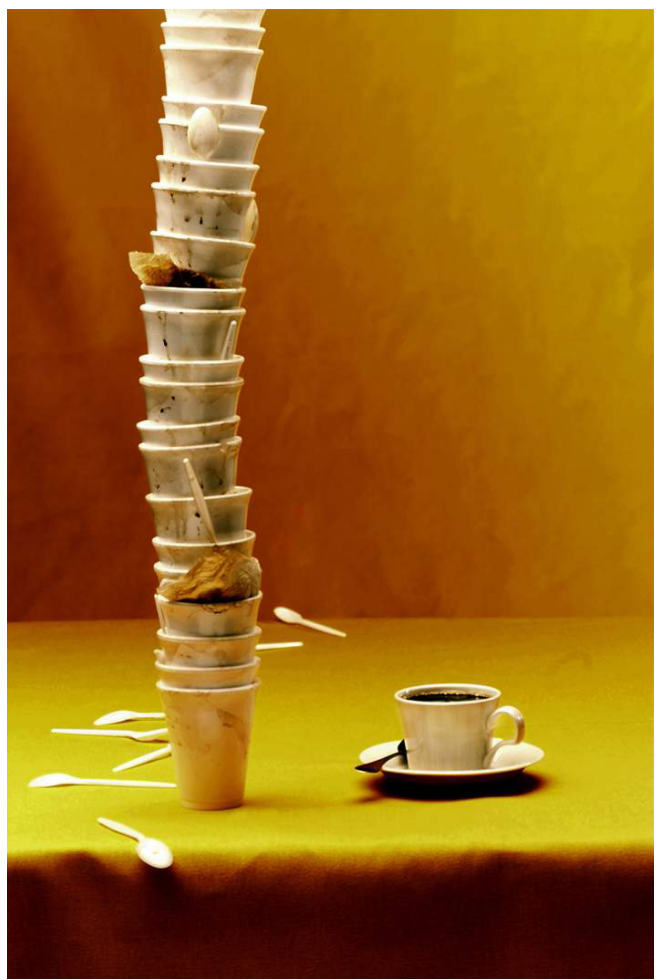

Figure 5: Awareness-raising campaign poster for households. 


\subsection{Distribution of material}

Training days, seminars and info spots are held in educational institutions, companies and offices of the public administration. Materials and methods are presented in different seminars both in Finland and other EU-countries. The goal is that the material will become widely known.

Information on these materials is also distributed to households along with different campaigns. The inhabitants have been approached with various kinds of awareness-raising campaigns towards households (Figure 5) and the aim is that the information has lead towards choices producing less waste.

The impressiveness of the project is being estimated by annual Gallup poll [13] to the residents in the Helsinki Metropolitan area (Figure 4). The resent study shows that the actions for waste prevention have not shown significant changes among the residents in 2003-2007. However the willingness to do for waste prevention has a large gap compared to the real actions taken.

\section{References}

[1] YTV's Waste Prevention Strategy 2007 and background study. The Publication Series of the Metropolitan Area (PSMA) C 2002:4, Helsinki.

[2] OECD, Towards Sustainable Household Consumption? Trends and policies in OECD countries. OECD Publications, Paris, 161 p., 2002.

[3] Autio, S. and Lettenmeier, M., Ekotehokkuus - Business as Future. Yrityksen ekoteho-opas (Eco-efficiency - Business as Future. Ecoefficiency guide for a company), Teknillinen korkeakoulu, Koulutuskeskus Dipoli, 84 p., 2003.

[4] Leinonen A.M., Rannikko S. and Taivassalo M., Verkossa ja verkostoissa, toiveita ja toteutuksia ammatillisen peruskoulutuksen virtuaalikouluhankkeissa. (Expectations and execution of virtual school projects concerning basic vocational education in the internet and networks), Opetushallitus, 65 p., 2003.

[5] Lundgren K. and Näätsaari H., Kohti kestävää ammatillista koulutusta. (Towards sustainable vocational education), Opetushallitus, 195 p., 2006.

[6] YTV (2007a): Parhaat käytännöt oppilaitoksessa (Smart Ways of Action for educational institutions), URL www.ytv.fi/FIN/toissa/oppilaitokset/ etusivu.htm

[7] YTV (2007b): Smart Ways of Action in retail stores, URL www.ytv.fi/ENG/fiksu/at_work/trade/frontpage.htm

[8] YTV (2007c): Parhaat käytännöt talonrakentamissa, (Smart Ways of Action in the building trade), URL www.ytv.fi/FIN/toissa/rakennusala/ etusivu.htm

[9] YTV, Smart Ways of Action in an office, URL, (2007d) www.ytv.fi/ENG/fiksu/at_work/office/frontpage.htm

[10] YTV (2007e): Parhaat käytännöt päivähoidossa (Smart Ways of Action in daycare centres), URL www.ytv.fi/FIN/toissa/oppilaitokset/etusivu.htm 
Ecosystems and Sustainable Development VI 529

[11] YTV, It's Smart with Less Waste website, URL, (2007f), www.ytv.fi/eng/fiksu

[12] YTV, Petra Waste Benchmarking Service, URL, (2007g), www.ytv.fi/petra

[13] TNS Gallup Oy (2007): Pääkaupunkiseutulaiset jäteasioista 2007. Sakari Nurmela, Itätuulenkuja 10, 02100 Espoo. 